\title{
French Teachers of English: Are They Trained to Teach English Pronunciation and Oral Comprehension Properly?
}

\author{
PESTY Marion \\ Laboratoire Ligérien de Linguistique UMR 7270 , Orléans, France
}

\begin{abstract}
Many researchers agree to say that English teachers generally lack adequate skills to teach pronunciation properly (Macdonald, 2002; Chen \& Goh, 2010), and that "there is a definite need for more courses for ESL teachers" (Derwing, 2010, p.27). We propose to present a survey that was conducted with 60 French primary school teachers and 71 secondary school teachers of English. The study was conducted in several private and public primary schools and high schools. Through a questionnaire, it focused on teachers' self-efficacy (i.e their "individual beliefs about their own abilities to perform [the teaching of English pronunciation] (...) and achieve specific results" (Chen \& Goh, 2010, p.333), on how the teachers working in these schools were trained (or not) to teach English pronunciation, and how they are used to working on pronunciation and oral comprehension in their classes. An analysis of the responses will make it possible to answer the following questions: what is the profile of primary school teachers and secondary school teachers in France? What are their needs and objectives? Are they capable of teaching English pronunciation efficiently and what can we objectively expect from them?
\end{abstract}

Index Terms -Pronunciation teaching, teachers' training, English teaching in France

\section{LITERATURE}

In recent years, several reports and studies have highlighted the difficulties that French learners encounter when it comes to acquiring a good command of English. Examples include the annual reports published by Education First. Each year, Education First publishes a ranking of English language skills by country, and between 2011 and 2019, France was consistently ranked among the countries of Europe where the mastery of English was one of the poorest. In 2013, French learners even had the weakest English skills in Europe, and the 2018's annual report stated that France still had persistent English skill deficiencies. A number of other studies have emphasized that these learning difficulties are particularly noticeable regarding both the acquisition of English pronunciation by French learners and the way they perceive the language (oral comprehension). This way, in 2019, the CNESCO published a report following a national survey on the teaching of foreign languages in French classes. This report stressed out that despite a will of the Ministry of National Education to emphasize the teaching of spoken English as soon as pupils start to learn an L2 (Official website of the Ministry, 2019), French pupils tend to face greater challenges in oral expression and comprehension than when having to write in English. In a study, Hilton (2003) noted that in 25\% of cases, French learners of English had not been able to identify a word in its spoken form even if they recognized its written form, nor to make the difference between 'hit' and 'eat' for example, which underlines that French learners face difficulties in understanding spoken English. Learning difficulties regarding the acquisition of English pronunciation by French learners of English have also been exposed in various publications (CNESCO, 2019; Henderson et al., 2012; Moore-Mauroux, 2010), and recurring errors have been identified, both at the segmental and suprasegmental levels (Herry-Bénit, 2011; Capliez, 2011).

However, these learning difficulties are not new, and in 1934, Chaffurin already stated that "English pronunciation [was] difficult for French people". This way, if learning English pronunciation has proved to be challenging for French learners for a long time now, one could wonder why the situation has not evolved over the last decades, as learning difficulties have clearly been identified. As far as French learners are concerned, Education First (2013) stressed out that both low exposure to English and declining skills among teenagers could be responsible for that persisting weak level in English, declaring: "It appears that the declining level of English ability in adults is led by young people, who are leaving school with weaker English than ever before. Examining English proficiency trends in teenagers over the past 15 years helps us understand the evolution in adult skill levels, and points to how the French school system is contributing to the overall decline. [...Also,] French students report lower levels of exposure to English in everyday life than any other Europeans polled". Indeed, researchers agree to say that these two factors, namely exposure (Piske et al., 2001; Moyer, 1999 ; Derwing et al., 2008 ; Celce-Murcia et al., 1996) and quality teaching (Saito, 2011, Derwing et al., 1998; Atli \& Bergil, 2012) affect the chances of learners to become fluent and/or native-like in an L2, in the same way as motivation for example (Marinova-Todd et al., 2000 ; Suter, 1976; Bongaerts, 1999). 
Following the publication of such reports since the 2000's, the French Ministry of National Education has introduced a number of educational reforms to try to help French pupils acquire solid skills in English, but without any real success. In that respect, several recent reports underline that from one year to another, despite these numerous reforms, French pupils English proficiency skills' are still stagnating or even declining (CNESCO, 2019; Taylor \& Manes-Bonnisseau, 2018; Education First, 2013). In this way, significant differences between the Government's expectations and the real level of French pupils have been highlighted. Taylor \& Mannes-Bonnisseau' report (2018), quoting the European Survey and data from Key Data on Language Teaching (2017), evoke the case of 15 years old French pupils who had started to learn English at 6, which represents more or less 936 hours of language learning in a school context. For such learners, the French Ministry of National Education expects a B1 level in the Common European Framework of Reference for Languages, but research has showed that only $11 \%$ of these pupils had actually reached this level after 9 years of English learning at school. Another 15\% had reached the A2 level, and $71 \%$ of the pupils had reached the A1 or A1- levels, which are the levels expected for a pupil leaving elementary school. These results are far below those of other European countries, such as Sweden for example, where $80 \%$ of the pupils with the same profile manage to reach either the B1 or even B2 levels after 9 years of English learning (CNESCO, 2019).

As underlined earlier in this article, these difficulties faced by French learners of English are particularly prominent regarding the acquisition of solid oral skills in L2 (pronunciation and oral comprehension of English). In this way, the CNESCO's report (2019) mentioned that a significant number of French pupils face difficulties in making themselves understood in English due to a hazardous pronunciation of English, which would be strongly influenced by their mother tongue. If Education First (2013) declared that the French school system might be responsible for that weak level, the CNESCO (2019) also pointed out the way oral English is taught in French classes and how it could explain why French learners of English do not manage to improve their spoken English over the years. In this report, reference is made in particular to the fact that since 2016 (Official Bulletin $n^{\circ} 39$, October 2015), the teaching of an L2 has become compulsory in France for any pupil entering primary school. However, this teaching is provided by primary school teachers, who are not specialists of English, as pointed out by the CNESCO (2019) which specified that "imposing the teaching of an L2 to teachers who are not specialists can be productive only if they are provided with adequate professional training". In this way, Derwing (2010) suggested that "an increased focus on pronunciation should extend to K-12 classroom teachers as well, even though they are not necessarily designated as language teachers per se". Literature also stressed out that even secondary school teachers tend to lack professional training to be able to teach English pronunciation and oral comprehension properly (MacDonald, 2002 ; Huart, 2010 ; Chen \& Goh, 2010), even if they are specialists. Such a lack of training has direct consequences on the level of their pupils, as claimed by Hodges (2006), who declared that many French speaking teachers never acquire some typically English phonemes and consequently transmit their incorrect pronunciation to their students.

The consideration of the elements mentioned above, namely the declining level of French pupils in English over the years, particularly regarding their oral skills, and the fact that such a persistent issue might be due to the lack of training of both French primary school teachers and secondary school teachers led us to implement the present study. We propose to present a survey that was conducted with 60 French primary school teachers and 71 secondary school teachers of English. The study was conducted in several private and public primary schools and high schools. Through a questionnaire, it focused on teachers' self-efficacy (i.e their "individual beliefs about their own abilities to perform [the teaching of English pronunciation] (...) and achieve specific results" (Chen \& Goh, 2010, p.333), on how the teachers working in these schools were trained (or not) to teach English pronunciation, and how they are used to working on pronunciation and oral comprehension in their classes. An analysis of the responses will make it possible to answer the following questions: what is the profile of primary school teachers and secondary school teachers in France? What are their needs and objectives? Are they capable of teaching English pronunciation efficiently and what can we objectively expect from them?

\section{SURVEY}

\section{A. Participants and Procedure}

Participants in this survey were 60 primary school teachers and 71 secondary school teachers from various private or public educational institutions. On average, primary school teachers had 19.5 years of experience in teaching. The least experienced teacher was in his first year of teaching, and the most experienced one in her $38^{\text {th }}$. Secondary school teachers had 16.5 years of experience on average, with experience in teaching going from 1 year of teaching to 37 . Out of the 60 primary school teachers who responded to the survey, 9 of them had an English diploma, the 51 others had made studies in the fields of History, mathematics, sciences, philosophy, Spanish or accounting for example ${ }^{1}$, and 31 had at least a bachelor's degree. 63/71 out of the secondary school teachers who participated in this survey had a Master's degree in English.

Before they were sent to teachers for this survey, the questionnaires had been developed and revised. Indeed, the instruments were piloted and read by several school inspectors (primary school inspectors and secondary school

\footnotetext{
${ }^{1}$ It has to be specified that in France, primary school teachers have to teach English, even if they have not studied the language during their postgraduate studies. Having an English diploma is not an obligation to teach English at this level in France.
} 
inspectors) in several French departments. These professionals had been asked to make comments or suggestions for clarification if needed before the questionnaires could be sent to teachers for a larger scale study. This way, once revised, the questionnaires were eventually sent out to teachers and then returned to us for analysis.

The questionnaires for the survey presented here focused on teachers' self-efficacy (i.e. their "individual beliefs about their own abilities to perform [the teaching of English pronunciation] (...) and achieve specific results" (Chen \& Goh, 2010), on how the teachers working in these schools have been trained (or not) to teach English pronunciation, and how they are used to working on pronunciation and oral comprehension in their classes. General questions about the teaching of English in French schools had also been added to the questionnaires.

\section{B. Results}

\section{Secondary School Teachers}

The 71 secondary school teachers who participated in the survey had to answer several questions about their professional training. First, it was found that $14 \%$ of them had never studied English pronunciation at all during their postgraduate studies. The other $86 \%$ had been trained, and a majority of them had studied different aspects of English phonetics. This way, as mentioned in Figure 1 below, teachers said that they had learned about the production of English vowels and/or consonants, or studied articulatory phonetics. As far as English prosody is concerned, secondary school teachers had also been trained, as their university education had included courses on stress, tones, and English rhythm. The detailed results are presented in the following graph:

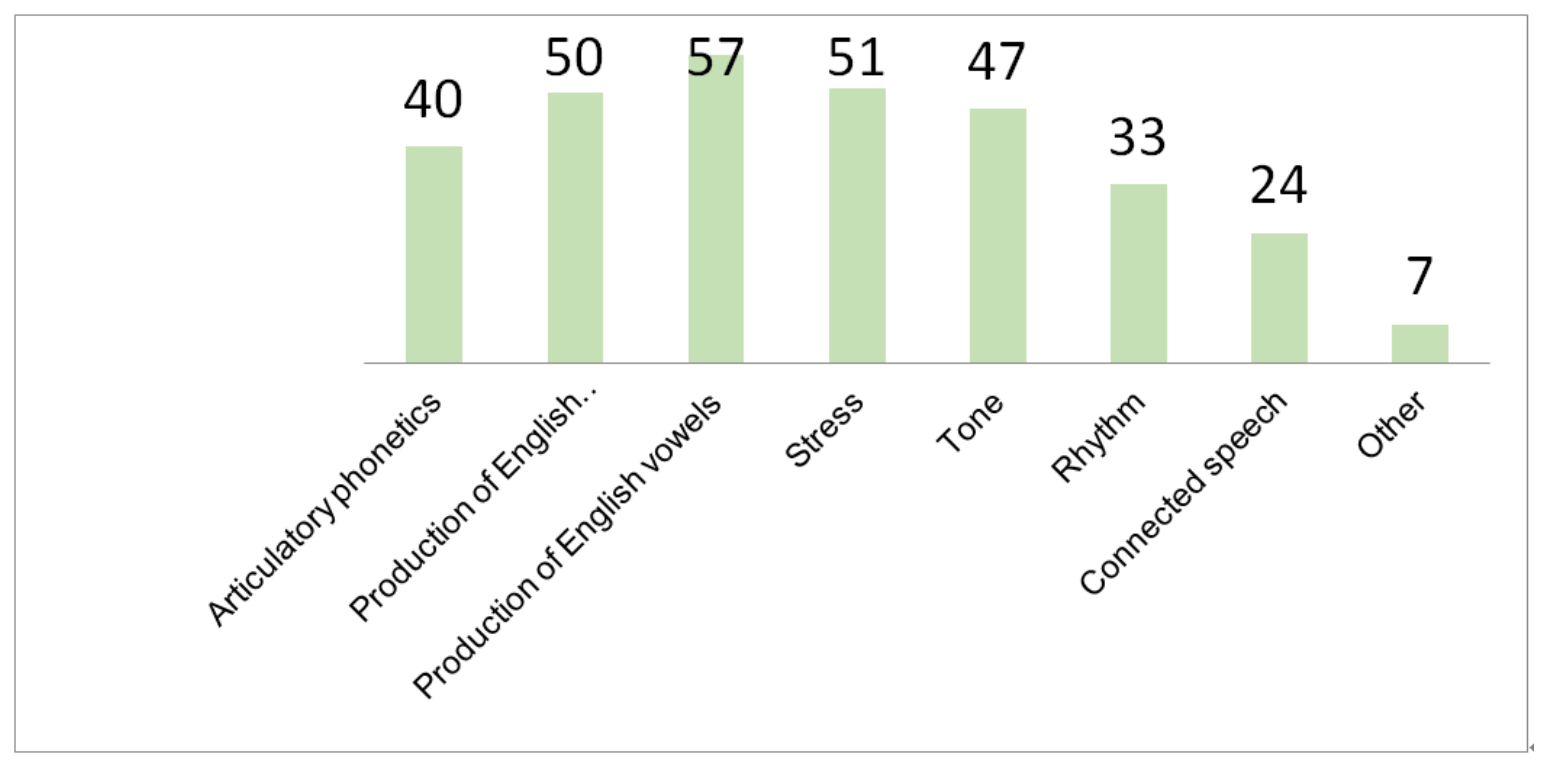

Figure 1: Content of Training - Secondary School Teachers

When asked if they thought that they had been trained to teach English pronunciation, only $10 \%$ of the interviewed teachers answered «Absolutely». Half of them (51\%) believed that they had been partially trained to teach it, and $39 \%$ felt that they had not really been trained for that. The results also show that only $26 \%$ of the teachers thought that their initial training helps them on a daily basis to teach pronunciation in class, whereas $74 \%$ of them affirmed that it is their professional experience which guides them when it comes to teaching English pronunciation.

The teachers were also asked whether they would be interested in a professional training to help them learn how to teach English pronunciation, and a majority of them answered positively since $84 \%$ claimed that they would like to be trained to teach pronunciation and / or deepen their knowledge of English phonetics for example.

Secondary school teachers were also asked questions about their pedagogical practices. Results suggest that only $21 \%$ of them systematically correct the pronunciation of the pupils in class when a word is mispronounced. A majority of them declared that they very regularly correct the pronunciation of their pupils (68\%), 10\% admitted that they correct it from time to time, and only $1 \%$ of them affirmed that they rarely do it. However, even if only $21 \%$ of the teachers affirmed that they always correct a mispronounced word, 35\% of the 71 interviewed teachers declared that they want their pupils to leave high school with a native-like pronunciation. Also, when asked the reasons why they sometimes deliberately omit to correct a mispronounced word in class, the following answers were given: 


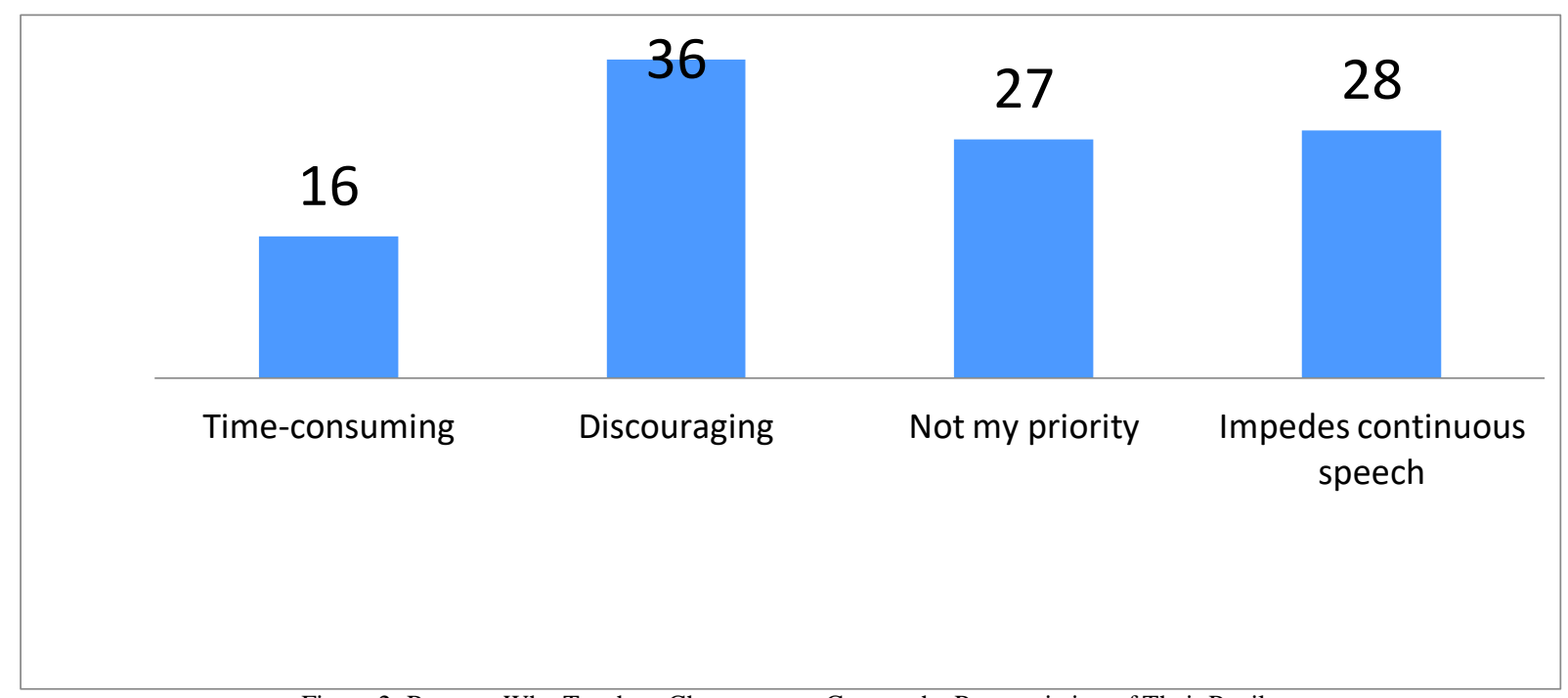

Figure 2: Reasons Why Teachers Choose not to Correct the Pronunciation of Their Pupils

Figure 2 shows that the discouraging aspect that represents a public correction for the pupil was the first reason mentioned by secondary school teachers to explain why they do not systematically correct a bad production of English segments or prosody (36 occurrences). Teachers also affirmed that a correction seems to be impeding continuous speech (27 answers). 27 of them declared that most of the time, correcting the pronunciation of their pupils is simply not their priority, and 16 said that it is time-consuming.

The survey also focused on how French teachers usually work on pronunciation in class. The top 8 answers given were:

1. Repetition of a target word

2. Tongue twisters

3. Reading (texts)

4. Songs

5. Minimal pairs

6. Phonetic transcription of key words

7. Work in a laboratory (computers)

8. Poems

As detailed above, we found that asking students to repeat a mispronounced word is the most common exercise used by French teachers to work on pronunciation in class, followed by the use of tongue twisters and reading activities. Other activities were also mentioned, although more rarely, like film dubbing or use of gestures to make pupils acquire English prosody, with one occurrence each.

Finally, the questionnaire included a more general question about the teaching of spoken English in French classes. Teachers were asked to give their opinion about this aspect of teaching, and to underline what could / should be improved in French classes to make it possible for pupils to acquire a better perception and production of spoken English. A total of 52 different issues were identified by secondary school teachers to explain why it might be challenging to teach English pronunciation efficiently. These included equipment issues, problems linked to the behaviour of pupils, constraints linked to classroom size and time for example. Some answers are detailed below:

«Too few hours available, and too many pupils in each class!»; «We need proficiency groups...»; «Pupils are completely discouraged!»; «Working in a lab is a good thing ... but it is time-consuming!»; «Course books and training manuals are not adapted»; «I don't know how to include a work on pronunciation that could have a link with the theme of my chapter»; «We do not have enough equipment / adapted equipment»; «The pupils have complexes that impedes work on pronunciation»; «Input outside of the class is a real problem!(TV, radio)»; «Pupils rely on the written form of English to talk, and I don't know what to do to prevent that»; «We definitely lack professional training !»;«Each time I have tried to teach pronunciation, it has always been a total failure, so I do not teach it anymore !»

However, one of the most cited answers was that the teaching of English in primary schools should be completely or at least partially revised in order to make it possible for secondary school teachers to work efficiently on pronunciation. This way, answers like «There is a real problem with the teaching of English in primary schools» or «The pronunciation of the pupils is far too poor when they arrive at secondary school level, we can do nothing, it's too late» were regularly given.

\section{Primary School Teachers}

The questionnaire started with self-assessment questions concerning teachers' opinion about their mastery of English perception and production. The detailed results are presented in the following graphs: 


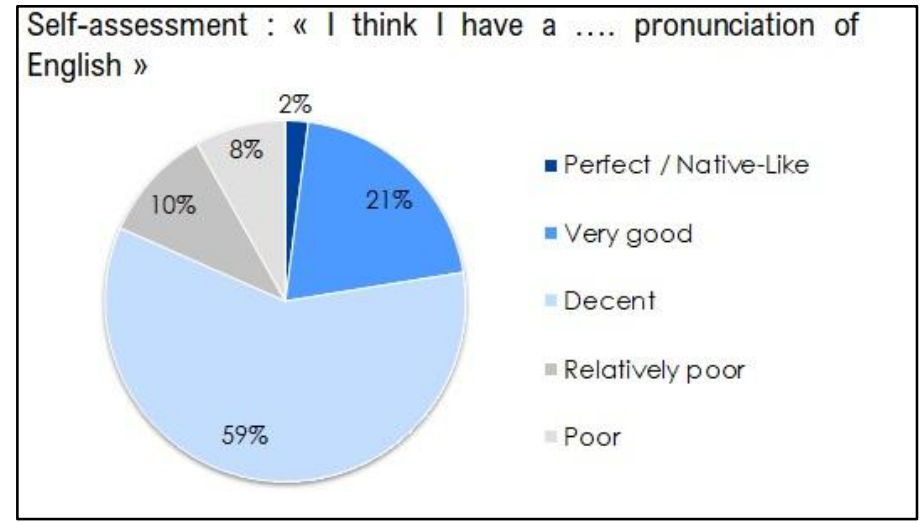

Figure 3: Self-assessment Question: Pronunciation of English by Primary School Teacher

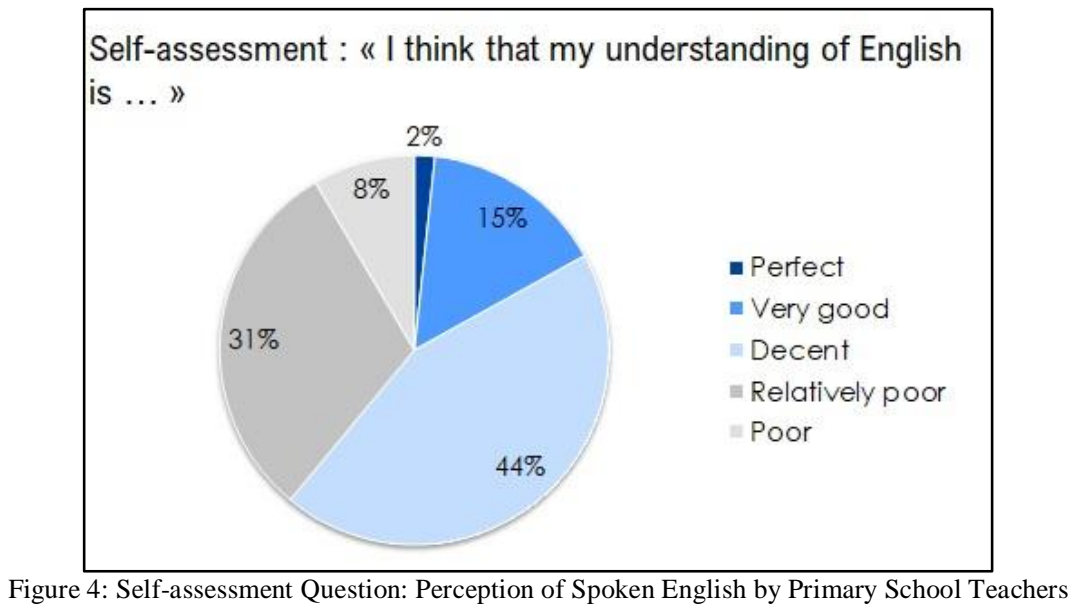

Data presented in figure 3 shows that only $2 \%$ of the primary school teachers who were interviewed think that they have a perfect / native-like pronunciation of English, and $21 \%$ believe that they have a very good pronunciation of English. Out of the 60 teachers who responded to the survey, 77\% of them thought that their pronunciation of English was at best decent, or even relatively poor or poor with shares of 59\%, $10 \%$ and $8 \%$ respectively. As far as their perception skills were concerned, figure 4 makes it possible to see that again, $2 \%$ of the teachers estimate that the have a perfect perception of spoken English. 15\% of them think that they have a very good perception of the language. Once more, with a total of $83 \%$ of responses, a majority of the respondents declared that their skills in oral comprehension of English were at best decent, or even relatively poor or poor, with shares of $44 \%, 31 \%$ and $8 \%$ respectively.

Primary school teachers were also asked questions about their professional training. It was found that barely a quarter of them affirmed that they had received pronunciation instruction during their postgraduate studies, and that only $17 \%$ declared that they had been trained to teach English during their professional career (initial training and vocational training taken together). As a consequence, $93 \%$ of the teachers who responded to the survey declared that they would like English to be taught to their pupils by another (qualified) person.

Questions about their practices were also included to the questionnaire. This way, it was emphasized that more than a half of the teachers (53\%) declared to teach English to their pupils less than one hour a week, with $15 \%$ teaching it less than 30 minutes a week. During that instruction time, only 5\% of the 60 teachers admitted that they rarely correct the pronunciation of their pupils, and $23 \%$ said that they do from time to time. $72 \%$ affirmed that a mispronounced word was corrected at least very regularly or even systematically, with shares of $40 \%$ and $32 \%$ respectively. Reasons evoked to explain why teachers might deliberately omit to correct the pronunciation of a pupil were not proportionally similar to those given by secondary school teachers. This way, even if 19 teachers also affirmed that systematic corrections are discouraging for learners, only one teacher said that it is time consuming. 8 answered that the acquisition of a good pronunciation is usually not their pedagogical priority, but 16 admitted that they almost never correct the pronunciation of the pupils simply because they think that they are not a good model for them and / or because they do not feel qualified to do it.

Finally, teachers were asked to affirm if they felt qualified to teach English production and perception. The results are detailed below: 


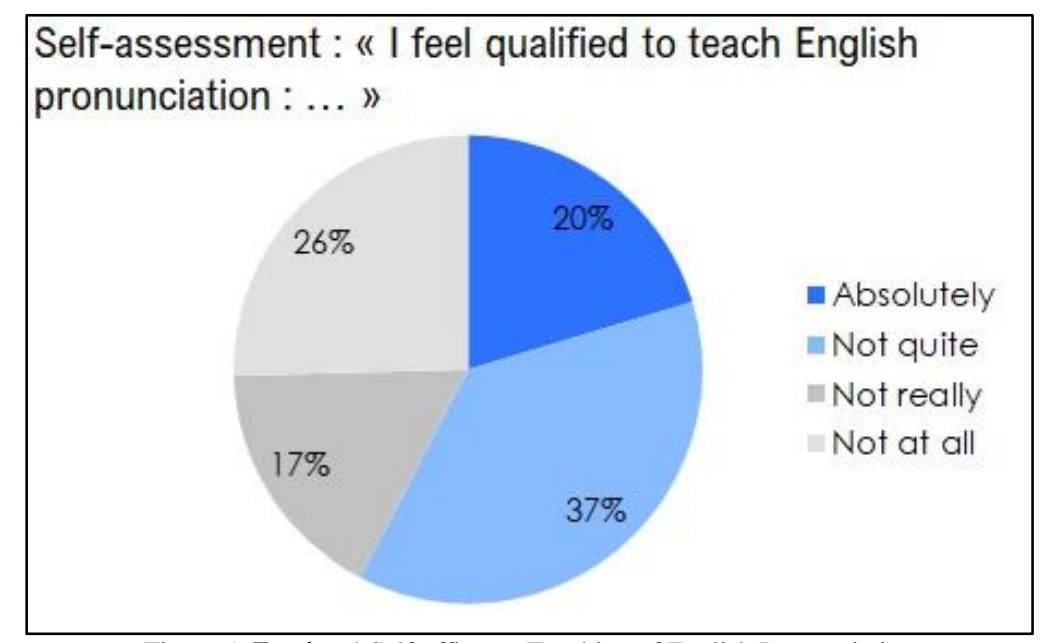

Figure 5: Teachers' Self-efficacy: Teaching of English Pronunciation

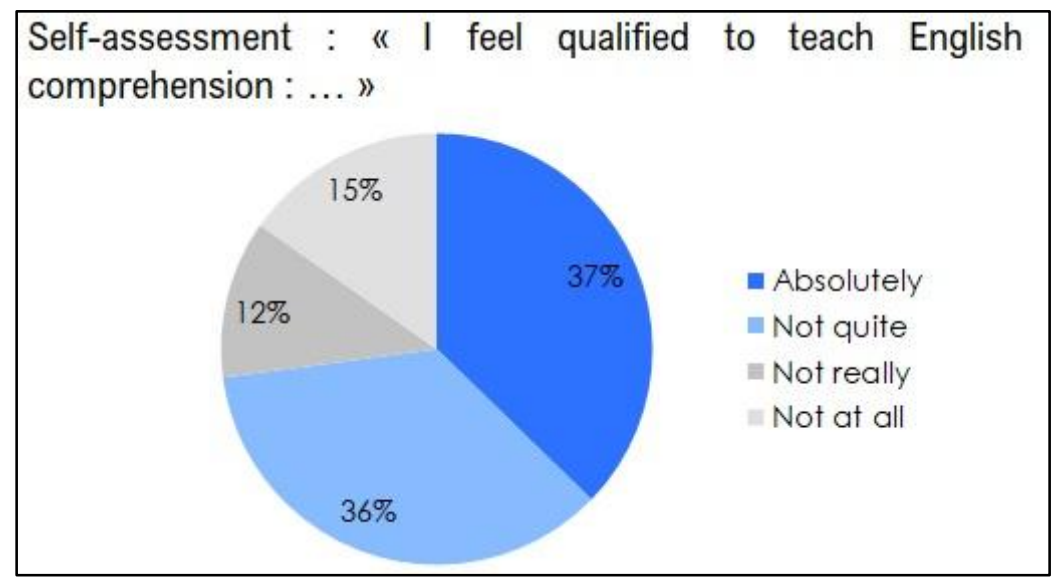

Figure 6: Teachers' Self-efficacy: Teaching of English Comprehension

Results presented in figure 5 suggest that only a fifth of the interviewed teachers think that they are fully qualified to teach English pronunciation. A half affirmed that they are either not completely qualified (37\%) or not really qualified $(17 \%)$ to do it, and about a quarter declared that they are not at all qualified to teach English segments and prosody, with $26 \%$ of respondents. As far as the teaching of oral comprehension is concerned, results are similar. Indeed, data presented in figure 6 underline that $37 \%$ of the teachers said that they are absolutely qualified to teach the perception of English phonemes and prosody to young learners. A total of $48 \%$ of them affirmed that they are either not completely $(36 \%)$ or not really qualified $(12 \%)$ to teach it, and $15 \%$ of the respondents declared that they do not feel qualified at all.

Again, it had been decided to ask teachers to make some general remarks about the teaching of English in French primary schools. A large majority of them declared that they should not teach English because they have not been trained for that. Plus, it was underlined that teachers have the feeling that their poor level in English has harmful consequences on the level of their pupils, who seem to be acquiring a bad pronunciation of English because of them, according to the responses that we collected. Here is a sample of answers that were made by the 60 primary schools teachers: «My English is damaging to the pupils»; «My level of English is so bad...»; «Teaching quality is limited by our competences in English»; «Secondary school teachers have to repair our mistakes». Collected answers also revealed that most of the time, teaching English, and especially English pronunciation, is a source of anxiety for French primary school teachers, for the reasons evoked above. This way, answers like «teaching English is a cause for concern»; «It is a nightmare for me »; «My colleagues are not comfortable with it »; «I feel neither at ease nor qualified when it comes to teaching English » were given.

\section{DISCUSSION}

This survey made it possible for us to highlight several elements. First, it seems that overall, French secondary school teachers have received instruction in English pronunciation, and a majority has some basic knowledge of English phonetics contrary to what can be claimed in literature (Breitkreutz et al., 2001; Macdonald, 2002). However, it has to be underlined that even if these teachers have at least some basic knowledge of English pronunciation (segments and prosody), it seems that they have not been trained to teach it in class. In other words, even if they know what to teach, they need help to learn how to teach it efficiently, and are increasingly in demand of professional training, although questionnaires made it possible to emphasize that most of the time, these vocational trainings are not granted. Also, 
even though no teacher affirmed that he/she has a $100 \%$ native-like pronunciation, $35 \%$ of them would like their pupils to leave high school with such a pronunciation, which is paradoxical. Another point that was raised by this survey is that generally speaking, secondary school teachers in France find it very challenging to teach English pronunciation in class for numerous reasons. The direct consequence of that is a minimal consideration of that aspect of spoken English in language courses, as pointed out by several researchers (Diana, 2010; Gilbert, 2010; Kelly, 1969). As far as primary school teachers are concerned, the survey revealed several worrying elements. First, it seems that a majority of them have neither been trained to master the pronunciation or perception of English themselves, nor to teach it to young learners. As a consequence, it was found that $93 \%$ of the interviewed teachers are not willing to teach English because they do not feel qualified to do it, and they would like to be supported or replaced by specialists of English to make it sure that French pupils benefit from effective teaching. Besides, a significant part of primary school teachers who answered the questionnaire declared that they have the feeling that their bad pronunciation of English tends to be transmitted to their pupils, and that generally, their shortcomings in English causes more harm than good. This phenomenon is described by Hodges (2006) or Flege (1991), who developed the accented L2 input hypothesis, which predicts that a learner who receives accented input instead of native or native-like input will be likely to develop in turn an accented pronunciation of English, or even be unable to develop good perception and production skills. This way, considering such a hypothesis, one could wonder if asking untrained primary school teachers to teach English pronunciation and oral comprehension to young learners is really constructive and helpful for children learning English as an L2. Also, perhaps that hiring specialists, as suggested by primary school teachers themselves, could be a good alternative, although it might be complex to implement.

\section{REFERENCES}

[1] Atli, I., Bergil, A. (2012). The effect of pronunciation instruction on students' overall speaking skills. Social and behavior science, 46, 3665-3671.

[2] Bongaerts, T. (1999). Ultimate attainment in L2 pronunciation: The case of very advanced late L2 learners. In D. Birdsong (Dir), Second language acquisition and the Critical Period Hypothesis. Mahwah, NJ : Erlbaum, 133-159.

[3] Breitkreutz, J., Derwing, T., Rossiter, M. (2001). Pronunciation Teaching Practices in Canada. TESL Canada Journal, 19 (1), 51-61.

[4] Capliez, M. (2011b). Typologie des erreurs de production d'anglais des francophones : segments vs. suprasegments. Recherches et pratiques pédagogiques en langues de spécialité, 30 (3), 44-60.

[5] Celce-Murcia, M., Brinton, D. M., Goodwin, J. M. (1996). Teaching pronunciation: A reference for teachers of English to speakers of other languages. Cambridge: Cambridge University Press.

[6] Celce-Murcia, M., Brinton, D., Goodwin, J. (2010). Teaching pronunciation - a reference for teachers of English to speakers of other languages. Cambridge University Press : New York.

[7] Chaffurin, L. (1934). Nouvelle grammaire anglaise à l'usage des français. Paris: Croville.

[8] Chen, Z., Goh, C. (2011). Teaching oral English in higher education: challenges to EFL teachers. Teaching in higher education, $16(3), 333-345$.

[9] CNESCO. (2019). De la découverte à l'appropriation des langues étrangères : Comment l'école peut-elle mieux accompagner les élèves? Recommandations du jury. Retrieved 22 November 2021 from http://www.cnesco.fr/wpcontent/uploads/2019/04/190411_Recommandations_juryLVE.pdf

[10] CNESCO. (2019). Langues vivantes étrangères: comment mieux accompagner les élèves ? Retrieved 22 November 2021 from https://www.cnesco.fr/fr/langues-vivantes-etrangeres-comment-mieux-accompagner-leseleves/

[11] Derwing, T. M., Munro, M. J., Wiebe, G. (1998). Evidence in Favor of a Broad Framework for Pronunciation Instruction. Language Learning, 48 (3), 393-410.

[12] Derwing, T. M., Munro, M. J., Thomson, R. I. (2008). A longitudinal study of ESL learners' fluency and comprehensibility development. Applied Linguistics, 29, 359-380.

[13] Derwing, T.M. (2010). Utopian goals for pronunciation teaching. Proceedings of the 1st Pronunciation in Second Language Learning and Teaching Conference, 24-37.

[14] Diana, A. (2010). La phonétique dans l'enseignement de l'anglais aux spécialistes d'autres disciplines : Enjeux et priorités. Recherche et pratiques pédagogiques en langues de spécialité, 29 (3), 10-21.

[15] European Commission, EACEA, Eurydice (2017). Key Data on Teaching Languages at School in Europe. Luxembourg: Publications Office of the European Union.

[16] EDUSCOL. (2019). Les épreuves du DNB. Retrieved 15 november 2019 from https://eduscol.education.fr/cid59348/lesepreuves-du-dnb.html

[17] EDUSCOL. (2019). Les réformes du Lycée. Retrieved 15 november 2019 from https://media.eduscol.education.fr/file/reformelycee2010/79/6/FAQLVsession2013_213796.pdf

[18] EF EPIP REPORTS. (2011-2019). EF EPI EF English Proficiency Index. Retrieved 15 November 2019 from https://www.ef.com/wwen/epi/downloads/

[19] Flege, J. E. (1991b). Perception and production: the relevance of phonetic input to L2 phonological learning. In T. Huebner and C. A. Ferguson (Eds.), Crosscurrents in Second Language Acquisition and Linguistic theories. Philadelphia : John Benjamins, 249-290.

[20] Henderson, A., Frost, D., Tergujeff, E., Kautzsch, A., Murphy, D., Kirkova-Naskova, A., Waniek-Climczak, E., Levey, D., Cunningham, U., Curnick, L. (2012). The English pronunciation teaching in Europe survey: selected results, Research in language, 10 (1), 5- 27.

[21] Herry-Bénit, N. (2011). Didactique de la phonétique anglaise. Rennes : Presses Universitaires de Rennes. 
[22] Hilton, H. E. (2003). L'Accès au lexique mental dans une langue étrangère : le cas de francophones apprenant l'anglais. CORELA, 1 (2), 25-43.

[23] Hilton, H. E. (2005). Théories d'apprentissage et didactique des langues. Les Langues modernes, 3, 12-21.

[24] Hodges, B. A. (2006). An EFL Pronunciation Course for French University Students. AL 8320 Sound System of English. Georgia State University.

[25] Huart, R. (2010). Nouvelle grammaire de l'anglais oral. Paris: Ophrys.

[26] Kelly, L. G. (1969). 25 Centuries of language teaching. Rowley MA : Newbury House.

[27] MacDonald, S. (2002). Pronunciation views and practices of reluctant teachers. Prospect, 17 (3), 3-18.

[28] Marinova-Todd, S.H., Marshall, D.B., Snow, C. E. (2000). Three misconceptions about age and L2 learning. TESOL Quarterly, 34 (1), 9-34.

[29] Moore-Mauroux, S. (2010). Quelques outils méthodologiques pour aider l'étudiant francophone face à la prononciation de l'anglais. Recherche et pratiques pédagogiques en langues de spécialité, 29 (3), 36-49.

[30] Moyer, A. (1999). Ultimate attainment in L2 phonology: The critical factors of age, motivation, and instruction. Studies in Second Language Acquisition, 21, 81-108.

[31] Official website of the French ministry of national education. (2014). Bulletin officiel $n^{\circ} 4$ du 23 janvier 2014. Retrieved 22 November 2021 from https://anglais.enseigne.ac-lyon.fr/spip/IMG/pdf/grilles_CO_EO_LV1_LV2_et_LV3.pdf

[32] Official website of the French ministry of national education. (2019). Bulletin officiel spécial n1 du 22 janvier 2019. Retrieved 15 november 2019 from https://www.education.gouv.fr/cid138218/au-bo-special-du-22-janvier-2019-programmesdenseignement-du-lycee-general-et-technologique.html

[33] Official website of the French ministry of national education. (2019). Retrieved 15 November 2019 from https://cache.media.education.gouv.fr/file/SP1-MEN-22-1- 2019/95/2/spe585_annexe1_1062952.pdf

[34] Official website of the French ministry of national education. (2020). Les Langues vivantes étrangères et régionales. Retrieved 22 november 2021 from https://www.education.gouv.fr/cid206/les-languesvivantesetrangeres.html\#Les_niveaux\%20de\%20comp\%C3\%A9tences\%20urop\%C3\%A9ens\%20cib les\%20pour\%201\%E2\%80\%99enseignement $\% 20$ des\%20langues $\% 20 \mathrm{en} \% 20 \mathrm{France}$

[35] Official website of the French ministry of national education. (2015). Bulletin officiel $n^{\circ} 39$ du 22 octobre 2015. Enseignement des langues vivantes étrangères et régionales La carte des langues vivantes. Retrieved 22 November 2021 from http://circulaire.legifrance.gouv.fr/pdf/2015/10/cir_40147.pdf

[36] Official website of the French Ministry of national education. (2018). Taylor, A., Manes-Bonnisseau, C. Propositions pour une meilleure maîtrise des langues vivantes étrangères - Oser dire le nouveau monde. Retrieved 22 november 2021 from https://www.education.gouv.fr/cid133908/propositions-pour-une-meilleure-maitrise-deslangues-vivantes-etrangeres.html

[37] Piske, T., MacKay, I. R. A., \& Flege, J. E. (2001). Factors affecting degree of foreign accent in an L2: a Review. Journal of Phonetics, 29, 191-215.

[38] Saito, K. (2011). Examining the role of explicit phonetic instruction in native-like and comprehensible pronunciation development : An instructed SLA approach to L2 phonology. Language Awareness, 20, 45-59.

[39] Suter, R. W. (1976). Predictors of pronunciation accuracy in second language learning. Language Learning, 26, $233-253$.

[40] Taylor, A., Manes-Bonnisseau, C. (2018). Propositions pour une meilleure maîtrise des langues vivantes étrangères - Oser dire le nouveau monde. [En ligne : https://cache.media.education.gouv.fr/file/Racine/33/4/propositions_meilleure_maitrise_langu es_vivantes_998334.pdf]

[41] Tergujeff, E. (2013). English Pronunciation Teaching in Finland. (Doctoral dissertation, University of Jyväskylä)

[42] Wong, S., Dealey, J., Leung, V., Mok, P. (2019). Production of English connected speech processes: an assessment of Cantonese ESL learners' difficulties obtaining native-like speech. The Language Learning Journal, 36 (2), 1-16.

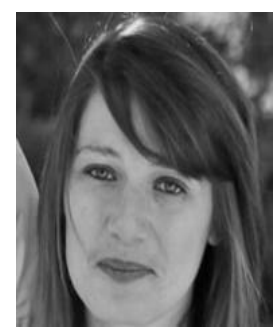

Marion L. PESTY was born in France in 1993. After earning a Bachelor's degree in English in 2014 and a Research Master's degree in 2016, she received a $\mathrm{PhD}$ in English linguistics and phonetics from the University of Orléans in France in 2019.

In 2016, she became a member of the LLL (Laboratoire Ligérien de Linguistique) and began to teach English linguistics, English phonetics and foreign language didactics at the University of Orléans - France. Her fields of research include the teaching of spoken English and the professional training of teachers. 